\title{
Regional environmental assessment of dairy farms
}

\author{
C. Alan Rotz, ${ }^{1 *} \odot$ Robert C. Stout, ${ }^{1} \odot$ Michael A. Holly, ${ }^{2}$ and Peter J. A. Kleinman ${ }^{1}$ \\ ${ }^{1}$ Pasture Systems and Watershed Management Research Unit, USDA-Agricultural Research Service, Building 3702 Curtin Rd., University Park, \\ PA 16802-3702 \\ ${ }^{2}$ Mechanical Engineering, University of Wisconsin-Green Bay, Green Bay 54311
}

\begin{abstract}
A comprehensive, yet in depth, assessment is needed of the environmental impacts of dairy farms at regional and national scales to better track improvements made by the industry. With Pennsylvania as an example, a method using process-level simulation and cradle-tofarm gate life cycle assessment was developed and used to assess important environmental footprints of dairy farms within a state. Representative dairy farms of various sizes and management practices throughout 7 regions of the state were simulated with the Integrated Farm System Model. Environmental footprints varied widely among farms, with this variation influenced primarily by soil characteristics and climate and secondarily by farm management. Therefore, prescriptive mitigation strategies for individual farms are more effective than uniform enforcement of specific strategies across the state. Footprints for the whole state were determined by totaling values among farms and regions based on the amounts of milk produced by each. Pennsylvania dairy farms were determined to emit 4,555 with an uncertainty of $\pm 415 \mathrm{Gg}$ of $\mathrm{CO}_{2}$ equivalent of greenhouse gas with an intensity of $0.99 \pm 0.09 \mathrm{~kg}$ of $\mathrm{CO}_{2}$ equivalent $/ \mathrm{kg}$ of fat- and protein-corrected milk (FPCM) produced. Fossil energy consumption was $12,324 \pm 1,946$ TJ or $2.69 \pm 0.42 \mathrm{MJ} / \mathrm{kg}$ of FPCM. Blue (nonprecipitation) water consumption was $64.1 \pm$ $13.5 \mathrm{Tg}$ with an intensity of $14.0 \pm 3.0 \mathrm{~kg} / \mathrm{kg}$ of FPCM. A total of all forms of reactive $\mathrm{N}$ loss was $43.2 \pm 5.0$ $\mathrm{Gg}$ with an intensity of $9.4 \pm 1.1 \mathrm{~g} / \mathrm{kg}$ of FPCM. These metrics were equivalent to $1.6 \%$ of the greenhouse gas emissions, $0.4 \%$ of fossil energy use, and $0.8 \%$ of fresh water consumption reported for the state. Thus, greenhouse gas emissions, fossil energy use, and blue water use associated with dairy farm production are relatively small compared with total estimates for the state. Perhaps the greatest environmental concern is that of ammonia emission, where dairy farms accounted for about
\end{abstract}

Received August 2, 2019.

Accepted December 4, 2019.

*Corresponding author: al.rotz@ars.usda.gov half the estimated emissions of the state. This method can be applied to assessments of the dairy industry at larger regional and national scales.

Key words: dairy farm, life cycle assessment, footprint, greenhouse gas, nitrogen loss

\section{INTRODUCTION}

The sustainability of US dairy farming hinges on many factors, from markets to regulations to land resources, all affecting the profitability of farming enterprises and their environmental footprint (von Keyserlingk et al., 2013). Dairy farming systems of the United States are diverse, varying across the nation's major regions and within individual states (Winsten et al., 2010; Holly et al., 2019). As a result, accurate assessment of the dairy industry and the nature of its impacts can be challenging. Indeed, many studies evaluating the environmental impacts of the dairy industry are either general in nature or, at the other extreme, specific to a particular location or production system (e.g., Capper et al., 2009; Thoma et al., 2013; O'Brien et al., 2014; Veltman et al., 2018). Objective, systematic approaches to assessments of the dairy industry are needed, particularly environmental assessments, that reflect the diversity of production practices found on farms at regional to national scales (IDF, 2015).

Dairy farming systems can be difficult to represent on a regional scale, given the range of practices found on individual operations, the overlap in practices between seemingly disparate systems, and the dynamic nature of the industry, where regular changes occur as a function of shifting markets, emergent technologies, and other pressures. Because of the diversity of farms found, Pennsylvania is an excellent state for defining protocols for regional assessments of dairy production. Holly et al. (2019) describe the diversity of dairy farming strategies in the state, from the degree of confinement and reliance on grazing, to organic certification, to the unique conditions of Amish dairies. Dairy farming is an important industry in Pennsylvania, with roughly 6,200 dairy farms, second only to Wisconsin in the number of dairies (Hoard's Dairyman, 2019). Pennsylvania ranks 
seventh among US states in the production of milk, producing 4.84 Tg in 2018 (Hoard's Dairyman, 2019).

Process-based modeling and simulation of farms provides a tool for evaluating diverse production systems. Simulation of production systems can provide a comprehensive assessment of environmental impacts along with other aspects of farm performance. Although this modeling approach has been widely applied to the evaluation of specific production systems (e.g., Rotz et al., 2010; Belflower et al., 2012; Veltman et al., 2018), application to regional and larger scale assessments has not been done for dairy farms. The Integrated Farm System Model (IFSM; Rotz et al., 2018) was recently used for a national assessment of the environmental footprints of beef cattle production (Rotz et al., 2019). In this assessment, representative cattle operations of various types and sizes were modeled throughout 7 geographic regions, and regional values were integrated to provide national-scale footprints. A similar approach to industry-wide assessment can be applied to dairy production, as proposed by Holly et al. (2019).

Our objective was to develop a method for quantifying important environmental footprints of dairy farm production in a region, selected to be the state of Pennsylvania. These footprints were determined as cradle-to-farm gate life cycle assessments of greenhouse gas (GHG) emissions, reactive nitrogen losses, fossil energy use, and blue (nonprecipitation) water consumption. Values determined were compared with those for the whole state to assess dairy's environmental impact relative to state-level estimates.

\section{MATERIALS AND METHODS}

Pennsylvania was divided into 7 dairy farming regions following county groups defined by the National Agricultural Statistics Service (Figure 1; NASS, 2019). Using the 5 dairy farm management types described by Holly et al. (2019), up to 10 farms were modeled in each of the regions. Farm types were (1) confined, (2) semi-confined, (3) management intensive grazing, (4) organic, and (5) Amish, with 2 farm sizes used for most types. Confined dairies are those where cattle are maintained in a barn, with the exception that heifers may be on pasture during the growing season. With semi-confined production, all cattle are maintained in barns most of the year, but some grazing is used in the summer months. Management intensive grazing is similar to semi-confinement production, but grazing is used more effectively with cattle defined to receive about $40 \%$ of their annual forage requirement from pasture (Holly et al., 2019). Organic farms also rely heavily on grazing while following organic production practices (Holly et al., 2019). Amish dairy farms are common

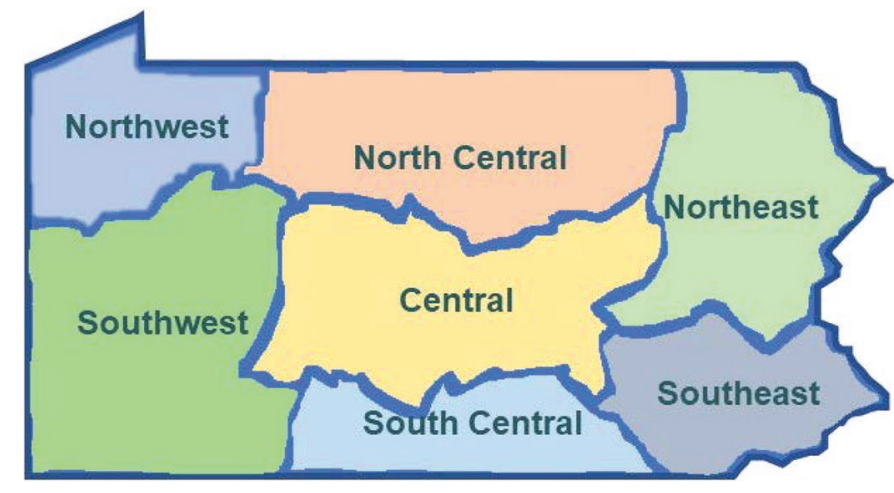

Figure 1. Regions in Pennsylvania used in our evaluation of the environmental footprints of dairy farms (adapted from NASS, 2019).

in a few regions of Pennsylvania. Amish are an ethnic group that farm without use of electricity and mobile equipment, and they rely on horses for conducting many farm operations. Their farms are generally small with a high animal density per unit of land farmed (Holly et al., 2019).

\section{Modeling Procedure}

Farms were simulated using the IFSM (USDA, 2018). The IFSM is a process-level simulation tool used to assess the performance, environmental impacts, and economics of dairy or beef production systems. Feed production and intake, animal growth and production, and the cycling of nutrients within the production system are simulated for many years of weather (Rotz et al., 2018). Nutrient movements are tracked to predict soil accumulation or attenuation and losses to the environment. Common paths of nitrogen (N) loss include ammonia $\left(\mathrm{NH}_{3}\right)$ volatilization, nitrous oxide $\left(\mathrm{N}_{2} \mathrm{O}\right)$ and $\mathrm{N}$ oxide emissions through nitrification and denitrification processes, and leaching and runoff of nitrate $\left(\mathrm{NO}_{3}^{-}\right)$. Process-based simulation predicts volatilization on an hourly time step and nitrification, denitrification, leaching, and runoff on a daily basis as influenced by temperature, wind speed, precipitation, soil conditions, and management practices (Rotz et al., 2014; Bonifacio et al., 2015; Rotz et al., 2018).

Previous studies have evaluated and verified the accuracy of IFSM in representing production systems. Comparing IFSM simulations of feed production and intake, fossil energy use, and production costs with actual records for the US Meat Animal Research Center showed differences of less than $1 \%$ during the study year of 2011 (Rotz et al., 2013). Numerous other studies have verified the model's ability to represent feed crop production, animal performance, emissions, and other components of the model in dairy production 
(e.g., Belflower et al., 2012; Rotz et al., 2014; Bonifacio et al., 2015; Jego et al., 2015; Leytem et al., 2018).

Following guidelines of the Livestock Environmental Assessment and Performance partnership (LEAP, 2016), a cradle-to-farm gate partial life cycle assessment is performed within IFSM to determine the annual carbon GHG emission, fossil energy use, blue water use, and reactive $\mathrm{N}$ loss (Rotz et al., 2018). Carbon is the sum of important emissions of methane $\left(\mathrm{CH}_{4}\right), \mathrm{N}_{2} \mathrm{O}$, and carbon dioxide $\left(\mathrm{CO}_{2}\right)$ converted to carbon dioxide equivalents $\left(\mathrm{CO}_{2} \mathbf{e}\right)$ using 100-yr global warming potentials of 28 for biogenic $\mathrm{CH}_{4}$ and 265 for $\mathrm{N}_{2} \mathrm{O}$ (Myhre et al., 2013). Emissions include both direct emissions from the production system as well as indirect $\mathrm{N}_{2} \mathrm{O}$ emissions that occur elsewhere in the environment resulting from a transformation of the $\mathrm{NH}_{3}$ and $\mathrm{NO}_{3}{ }^{-}$lost from the production system (IPCC, 2006a). Fossil energy use includes that of fuel and electricity used in milking and housing of animals, farm operations, and general truck use. Blue water is primarily that used for irrigated crop production, parlor cleaning, cattle consumption, and cooling of cattle. Reactive $\mathrm{N}$ is the sum of all $\mathrm{N}$ leaving the production system in the forms of $\mathrm{NH}_{3}, \mathrm{~N}_{2} \mathrm{O}, \mathrm{NO}$, and $\mathrm{NO}_{3}{ }^{-}$.
Emissions associated with the production of resources used on dairy operations (upstream sources) are included in the life cycle assessment (Rotz et al., 2018). Upstream sources include the production of fuel, electricity, fertilizer, purchased feed, machinery, seed, and pesticide. Emission or consumption values used for these upstream sources are listed in Table 1. Estimates of upstream contributions for purchased corn and forage were obtained using IFSM simulations of crop farms, where environmental impacts were divided by the feed produced and added to that for transport of feeds. Simulations of heifer raising operations were also used to determine a footprint for producing replacement heifers. This value was applied to excess heifers sold from the farm or any needed beyond those produced on the farm. An allocation method recommended by the International Dairy Federation (IDF, 2015) was used to determine the portion of the farm footprints to be appropriated to animals leaving the farm for use in beef production. This allocation was based on the BW of calves and cull cows exported relative to the milk weight sold.

In our analysis, environmental footprints include intensities expressed per unit of milk produced. Because

Table 1. Footprints for the production of purchased resources and feeds, including transport and upstream sources, used in the Integrated Farm System Model to determine cradle-to-farm gate footprints of dairy production systems in Pennsylvania

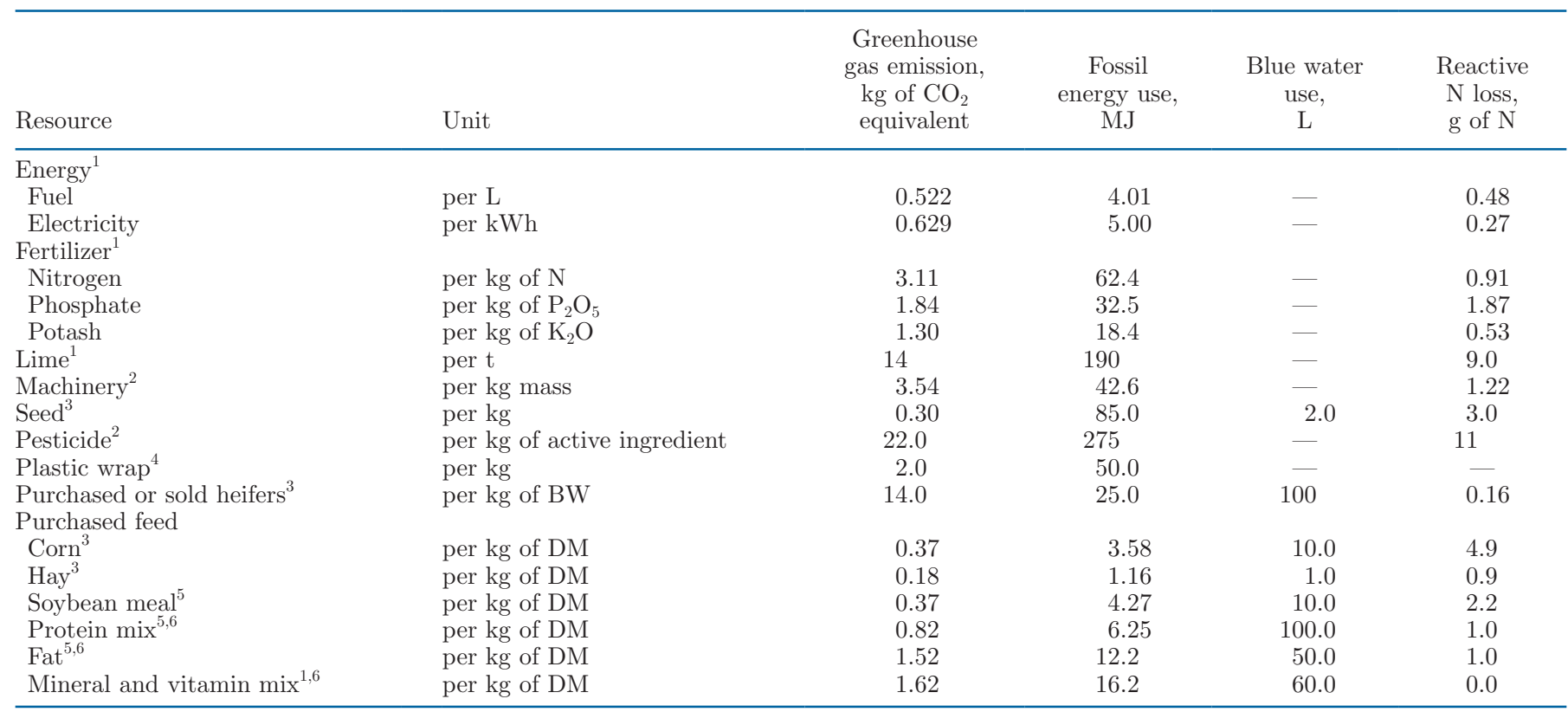

${ }^{1}$ Obtained from BASF's eco-efficiency analysis tool representative of US national values (BASF, Ludwigshafen, Germany).

${ }^{2}$ Obtained from the Greenhouse Gases, Regulated Emissions, and Energy use in Transportation (GREET) model (Argonne National Laboratory, Argonne, IL).

${ }^{3}$ Obtained from simulated farms using the Integrated Farm System Model (USDA, 2018).

${ }^{4}$ Rotz et al. (2010).

${ }^{5}$ Derived from simulations of corn and soybean crop farms in each region using the Integrated Farm System Model (USDA, 2018) and processing resource use with an economic allocation among the coproducts of the grains produced.

${ }^{6}$ Unpublished data (Greg Thoma, University of Arkansas, Fayetteville). 
the solids content of milk varies among production systems, the milk produced was converted to fat- and protein-corrected milk (FPCM) adjusted to $4.0 \%$ fat and $3.3 \%$ protein (IDF, 2015; Rotz et al., 2018).

\section{Representative Dairy Production Systems}

Current dairy farms in Pennsylvania vary in size from small ( $<20$ cows) to large (the largest maintaining up to 3,000 cows), with an average herd size around 80 milking cows (NASS, 2019). Model parameters describing representative dairy farms throughout the state were set considering survey data reported by Holly et al. (2019). Fifty-eight farms were simulated, ranging in size from a 15-cow Amish dairy to a 1,000-cow confinement operation (see Supplemental Data; https://doi.org/10 $.3168 /$ jds.2019-17388). Most of the farms maintained 50 to 100 cows, which is typical of current practice in Pennsylvania. Crop areas varied from 13.5 ha on the small Amish farm to 1,240 ha on large confinement farms. Predominant crops were corn silage, corn grain, alfalfa hay or silage, grass hay or silage, and winter rye or spring oat silage. Soybeans, which are found on some dairies in southern regions of the state, were also included as a cash crop on a few farms. Although farm parameters varied across regions, general descriptions of the representative farms are outlined in Table 2.

Cropping systems, including pasture use, were set up to represent that found by Holly et al. (2019) for each farm type (Table 2). Model parameters for each simulated crop were set to obtain long-term yields reported by NASS (2019) for each region using the soil and weather data for the region. Except for organic farms, inorganic fertilizer was used on all farms to supplement that available from manure. For the organic farms, pasture legumes and the recycling of manure nutrients were primarily used to meet crop needs. In southern regions, imported poultry manure was also used for organic crop nutrients. For other farms, inorganic fertilizer application rates varied from 20 to $50 \mathrm{~kg}$ of N/ ha depending on crop needs. On most of the farms that produced alfalfa, lime was applied to this crop at an average annual rate of $1.3 \mathrm{t} / \mathrm{ha}$. On the largest farm, lime was also applied to grass and corn at an average annual rate of $0.7 \mathrm{t} / \mathrm{ha}$. Phosphate and potash fertilizers were not needed on most farms, but they were used on the largest farm to meet crop requirements. The planting and harvest dates of crops and the relative maturity index of corn were varied to best represent agronomic practices in each region.

Corn was harvested as silage on all farms that grew corn. When silage production exceeded silo capacity, remaining corn was harvested and fed as high-moisture or dry grain. Alfalfa and grass were harvested as silage or dry hay for preservation. Tower silos were used on smaller farms, with some use of bagged silage (Holly et al., 2019). On farms with more than 100 cows, bunker silos were used for faster filling and removal of feed. Dry hay was normally stored inside a shed to reduce losses and preserve nutrients.

By definition, pasture was used on the organic, intensive grazing, and semi-confinement farms, and it was also used on Amish farms. The smaller confinement farms included grazing of replacement heifers. Grazing normally occurred for 5 to 6 mo of the year. For the intensive grazing farm, this was stretched to 7 mo through stockpiling of forage. A portion of the pasture was normally harvested as hay or silage in late spring and sometimes summer to preserve feed for winter feeding and to maintain forage quality in pastures.

Most farms produced enough forage to meet herd requirements. An exception was the Amish farms, where the high animal density did not allow enough crop production to meet all forage needs (Holly et al., 2019). Corn grain was commonly grown, but only the largest $(1,000$ cow $)$ farms produced enough to meet that

Table 2. General characteristics of representative dairy farms simulated in various regions of Pennsylvania

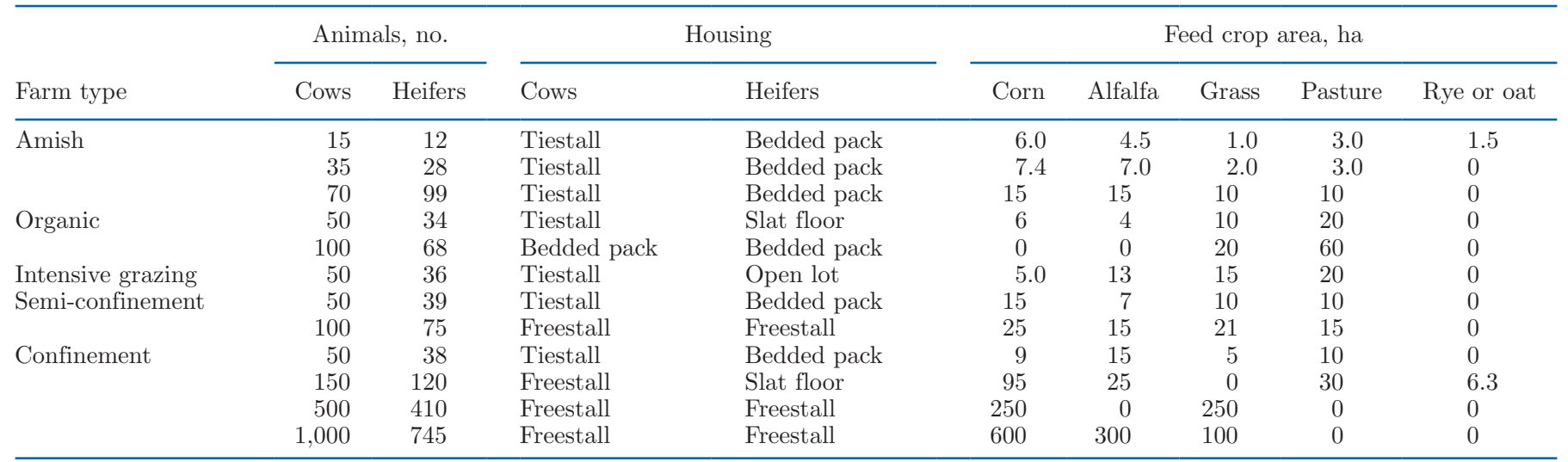


needed to feed the herd. Purchased supplemental feeds were used to meet or exceed protein and mineral requirements, where requirements were determined using functions from the NRC (2001) as implemented by Fox et al. (2004). Fat was included as an energy supplement in rations for the highest producing herds.

Herd size and characteristics were set to represent typical farms in Pennsylvania (Holly et al., 2019). Cattle genetics were primarily average-sized Holsteins with some variation. The organic farms used smaller animals representing a Holstein $\times$ Jersey crossbred, and the larger farms (>100 cows) used larger framed Holstein cattle for potentially greater feed intakes and milk production. Lactating cow replacement rates varied from a low of $25 \%$ for some of the organic and intensive grazing farms to a high of $38 \%$ for the high-producing confined herds. A random calving cycle was used on all farms except the intensive grazing and large organic farms, where spring calving was used. On these 2 farm types, grazing had a major role, and spring calving better aligned pasture availability with animal needs.

Animal housing and manure handling systems were set following the characteristics reported by Holly et al. (2019). Smaller farms (<100 cows) used tiestall barns with daily manure hauling and short-term manure storage. Heifers were normally housed in bedded-pack barns where accumulated manure was removed and applied to fields in the spring and fall. Thus, manure from these farms was handled in semisolid and solid forms. On a couple farms, heifers were reared in slatted-floor barns where manure collected as a slurry in a pit under the floor. On larger farms (100 or more cows), cattle were housed in freestall barns where manure was removed daily, stored in a slurry form for up to 6 mo in a tank, and then surface applied to cropland. For the largest farm, a flush removal system was used with a liquid-solid separator, and removed solids were recycled as bedding material. The liquid portion was stored in an earthen basin for up to 6 mo and surface applied to cropland in the spring and fall. Slurry and liquid manures were incorporated by tillage within $2 \mathrm{~d}$ of application.

\section{Regional and State Analyses}

From 7 to 10 representative farms were simulated in each of Pennsylvania's farming regions following the general description in Table 2. Not all farm types were included in each region. Amish farms were primarily found in the southeast, south central, and central regions, and the largest (1,000-cow) confinement farms were only in these regions, thus they were not used in the other 4 regions. Farms were simulated using weather and soils representative of each region (Tables 3 and 4). Simulations were done over 20 to $25 \mathrm{yr}$ of historical daily weather. Weather data were obtained from the Integrated Surface Database of the National Climatic Data Center of the National Oceanic and Atmospheric Administration (NOAA, 2019). Daily data included solar radiation; minimum, maximum, and mean temperature; precipitation; and wind speed. Soil characteristics were obtained from the Web Soil Survey (NRCS, 2019). An area of interest was defined over farmland in each region, and predominate soils were identified. Characteristics used were soil textures of clay, silt and sand contents, bulk density, and available water-holding capacity (Table 4).

From the simulations, environmental metrics were determined for each farm within each of Pennsylvania's farming regions. These included GHG emissions, reactive $\mathrm{N}$ losses, fossil energy consumption, and blue water use. An intensity of each was determined for each farm by dividing the total by the amount of FPCM produced. A weighted average of each intensity was determined for each region, where the weighting factor was the portion of total milk produced that came from each farm type. This factor was determined as the portion of farms of a given type in the region times the average herd size for that farm type times the average milk production per cow of that farm type. Data on average herd size and production level of each farm type were reported by Holly et al. (2019). Because not all farm types were found in each region, further adjustment was needed. When certain farm types were not found in a given region, the factors for the remaining farm types were increased proportionally. An additional adjustment across farms was then done to ensure that the average milk production per cow in the region agreed with that reported by NASS (2019). Although the factors varied among regions, the largest factors were for the small (50-cow) semi-confinement, small (50-cow) confinement, medium (150-cow) confinement, and large (1,000-cow) confinement farms, with about 13, 17, 39, and $14 \%$ of the milk coming from each, respectively (see Supplemental Data; https://doi.org/10.3168/jds .2019-17388). The remaining milk came from organic (2\%), Amish (7\%), intensive grazing (4\%), and large semi-confinement (4\%) farm types.

Footprints for the full state were determined using the regional intensities and milk produced in each region. Our regions corresponded to those defined by the National Agricultural Statistics Service (NASS, 2019), which provided the amount of milk produced by region. Total state footprints could then be determined as the sum of the regional intensities times the amount of milk produced in each region (Tables 5 and 6). Average in- 
tensities for the state were then determined as the state total emission or consumption divided by the total milk produced in the state.

To provide perspective on the values determined, the average annual environmental footprints for Pennsylvania dairy farms were compared with totals reported for the state. For GHG emissions, the Pennsylvania Department of Environmental Protection provides annual estimates broken down by sector. The latest data available were for 2015 (PA DEP, 2018), where agriculture contributed $2.7 \%$ of the total for the state. The US Energy Information Administration reports annual estimates for the total fossil energy consumption by state, where the latest available data were for 2016 (US EIA, 2019). The US Geological Survey reports annual water withdraws for each state, where the most recent data were for 2015 (Dieter et al., 2018). Fresh water, which is generally equivalent to blue water in our study, was reported as the total of that withdrawn from ground and surface waters. For total reactive N loss, state-level data were not available for comparison. The US Environmental Protection Agency does provide $\mathrm{NH}_{3}$ and $\mathrm{N}$ oxide emission estimates by state, with the latest available data for 2014 (US EPA, 2019). These data were compared with our corresponding farmgate life cycle data determined for Pennsylvania dairy farms. Although these comparisons are based on different methods and boundaries, they provide a general quantification of the dairy farm impacts relative to documented values for the whole state. These comparisons to state-level values do not assume that all resource flows are internal to Pennsylvania, but they do place dairy industry impacts in a broader context of state totals.

\section{Sensitivity and Uncertainty Analyses}

Some factors and assumptions may affect the accuracy and confidence in the results of this analysis. The state currently has over 6,000 dairy farms, and we represented all of these farms using 58 simulated farms. This provided a reasonable number of farms for this type of simulation analysis, but this is a relatively small portion of all farms and conditions. The nutrient management data used to support the model were not as complete as desired. The most recent data available on manure management were those reported in 2010, and these data did not report the amount of inorganic fertilizer used (Holly et al., 2019). Stable management practices were assumed for our farm simulations, so long-term changes in soil OM and related impacts on carbon and nitrogen levels were not considered. In view of these potential variabilities in the results, sensitivity and uncertainty analyses were conducted.

Sensitivity analyses were carried out to evaluate the relative influence of the individual components on each predicted environmental footprint using a previously documented procedure (Rotz et al., 2015). This analysis is useful for identifying components that have the greatest effect on predicted emissions or resource use and for indicating the associated error if an incorrect assumption existed affecting this component. A sensi-

Table 3. Summary of $25 \mathrm{yr}$ of weather data (daily solar radiation, daily mean temperature, annual precipitation, and daily wind speed) ${ }^{1}$ used in simulating dairy farms in each region of Pennsylvania

\begin{tabular}{|c|c|c|c|c|c|c|c|c|}
\hline Region and city & \multicolumn{2}{|c|}{ Solar radiation, $\mathrm{MJ} / \mathrm{m}^{2}$} & \multicolumn{2}{|c|}{ Temperature, ${ }^{\circ} \mathrm{C}$} & \multicolumn{2}{|c|}{ Precipitation, $\mathrm{mm}$} & \multicolumn{2}{|c|}{ Wind, $\mathrm{m} / \mathrm{s}$} \\
\hline Allentown & 13.8 & 0.84 & 11.1 & 0.66 & 1,158 & 172 & 3.3 & 0.37 \\
\hline Scranton & 13.5 & 0.69 & 10.0 & 0.64 & 956 & 174 & 3.1 & 0.42 \\
\hline \multicolumn{9}{|l|}{ Southeast } \\
\hline Lancaster & 13.3 & 1.33 & 12.1 & 0.85 & 1,074 & 167 & 3.6 & 0.38 \\
\hline Williamsport & 13.2 & 0.70 & 10.5 & 0.66 & 1,059 & 164 & 3.0 & 0.38 \\
\hline Dubois & 12.8 & 0.84 & 8.9 & 1.06 & 1,081 & 172 & 3.3 & 0.33 \\
\hline \multicolumn{9}{|l|}{ Central } \\
\hline State College & 13.4 & 0.68 & 10.2 & 0.80 & 1,006 & 197 & 2.8 & 0.28 \\
\hline Lewistown & 13.4 & 0.68 & 11.0 & 0.68 & 1,067 & 197 & 2.8 & 0.28 \\
\hline \multicolumn{9}{|l|}{ South central } \\
\hline Chambersburg & 13.8 & 1.25 & 11.7 & 0.67 & 1,084 & 216 & 3.4 & 0.46 \\
\hline
\end{tabular}

${ }^{1}$ Obtained from the Integrated Surface Database of the National Climatic Data Center, National Oceanic and Atmospheric Administration (NOAA, 2019). 
tivity index was determined as the ratio of the percent change in the assessed output over a 10\% change in the tested component. This procedure ignores potential interactions among components. A sensitivity index close to zero indicates low sensitivity and, hence, little change in the predicted output as a result of a change in the component. The converse is true for sensitivity indices close to or greater than one. Sensitivity indices were determined for each of the major sources of each environmental footprint for each region within Pennsylvania. Values were similar across regions, so the average of all regions was used to illustrate the sensitivity to full state predictions.

To quantify the confidence in predicted environmental footprints of the production systems, an uncertainty analysis was done following procedures previously used in an assessment of beef cattle production systems (Rotz et al., 2015). The uncertainty for each predicted

Table 4. Soil characteristics used for locations simulated across Pennsylvania

\begin{tabular}{|c|c|c|c|c|c|}
\hline \multirow[b]{2}{*}{ Location and soil type } & \multicolumn{3}{|c|}{ Soil texture, ${ }^{1} \%$} & \multirow{2}{*}{$\begin{array}{l}\text { Density, } \\
\mathrm{g} / \mathrm{cm}^{3}\end{array}$} & \multirow{2}{*}{$\begin{array}{c}\text { Available } \\
\text { water },{ }^{2} \mathrm{~mm}\end{array}$} \\
\hline & Clay & Silt & Sand & & \\
\hline \multicolumn{6}{|l|}{ Northeast } \\
\hline Leck kill channery silt loam & 15 & 55 & 30 & 1.35 & 140 \\
\hline Wellsboro channery loam & 16 & 48 & 36 & 1.25 & 110 \\
\hline Morris channery loam & 17 & 48 & 35 & 1.14 & 81 \\
\hline Hartleton channery silt loam & 18 & 53 & 29 & 1.30 & 100 \\
\hline \multicolumn{6}{|l|}{ Southeast } \\
\hline Berks-Weikert complex & 21 & 44 & 35 & 1.35 & 69 \\
\hline Chester silt loam & 22 & 55 & 23 & 1.37 & 170 \\
\hline Duffield silt loam & 20 & 59 & 21 & 1.34 & 160 \\
\hline Buck silt loam & 23 & 54 & 23 & 1.44 & 180 \\
\hline Gladstone gravelly loam & 15 & 45 & 40 & 1.44 & 140 \\
\hline Hagerstown silty-clay loam & 31 & 54 & 15 & 1.36 & 160 \\
\hline Hagerstown silt loam & 21 & 64 & 15 & 1.42 & 120 \\
\hline \multicolumn{6}{|l|}{ North central } \\
\hline Berks channery silt loam & 14 & 65 & 21 & 1.35 & 75 \\
\hline Volusia channery silt loam & 18 & 60 & 22 & 1.35 & 100 \\
\hline Lordstown channery silt loam & 14 & 56 & 30 & 1.17 & 121 \\
\hline Allenwood gravelly silt loam & 18 & 53 & 29 & 1.30 & 100 \\
\hline Mardin channery silt loam & 14 & 60 & 26 & 1.25 & 96 \\
\hline \multicolumn{6}{|l|}{ Central } \\
\hline Opequon silty clay loam & 38 & 48 & 14 & 1.33 & 100 \\
\hline Hagerstown silt loam & 21 & 64 & 15 & 1.38 & 150 \\
\hline Edam complex & 25 & 51 & 24 & 1.35 & 130 \\
\hline Hublersburg cherty silt loam & 21 & 53 & 26 & 1.30 & 140 \\
\hline Calvin-leck kill shaley silt loam & 18 & 53 & 29 & 1.30 & 100 \\
\hline Hagerstown silty clay loam & 31 & 53 & 16 & 1.36 & 160 \\
\hline \multicolumn{6}{|l|}{ South central } \\
\hline Hagerstown silt loam rocky & 25 & 55 & 20 & 1.36 & 180 \\
\hline Hagerstown-carb silty clay loam & 31 & 51 & 18 & 1.30 & 180 \\
\hline Berks channery silt loam & 15 & 64 & 21 & 1.35 & 100 \\
\hline Weikert channery silt loam & 21 & 52 & 27 & 1.37 & 100 \\
\hline Hublersburg cherty silt loam & 21 & 53 & 26 & 1.25 & 155 \\
\hline Hagerstown silt loam & 21 & 64 & 15 & 1.38 & 150 \\
\hline Chester silt loam & 22 & 54 & 24 & 1.35 & 182 \\
\hline \multicolumn{6}{|l|}{ Northwest } \\
\hline Cambridge silt loam & 12 & 59 & 29 & 1.30 & 130 \\
\hline Platea silt loam & 20 & 64 & 16 & 1.35 & 155 \\
\hline Venango silt loam & 17 & 60 & 23 & 1.30 & 122 \\
\hline Frenchtown silt loam & 20 & 58 & 22 & 1.27 & 126 \\
\hline Mill silt loam & 24 & 59 & 17 & 1.30 & 186 \\
\hline \multicolumn{6}{|l|}{ Southwest } \\
\hline Cavode silt loam & 34 & 54 & 12 & 1.34 & 138 \\
\hline Dormont silt loam & 22 & 65 & 13 & 1.33 & 149 \\
\hline Gilpin channery silt loam & 8 & 60 & 32 & 1.43 & 114 \\
\hline Wharton silt loam & 18 & 53 & 29 & 1.31 & 170 \\
\hline Rayne-Gilpin channery silt loams & 26 & 54 & 20 & 1.46 & 130 \\
\hline Ravenna silt loam & 15 & 62 & 23 & 1.40 & 129 \\
\hline
\end{tabular}

${ }^{1}$ Soil characteristics based on common soils found in each region as obtained from the Web Soil Survey (NRCS, 2019).

${ }^{2}$ Available water-holding capacity of the soil profile. 
environmental footprint was determined from the uncertainties in predicting each contributing source. As is characteristic of biological systems, statistical determination was limited by the unavailability of measured data. Thus, the uncertainties of the major sources of each footprint were set and refined following recommendations of the IPCC $(2006 a, b)$ based on their Tier 2 methods. The square root of the sums of squares of each major source multiplied by its estimated uncertainty gave the predicted footprint's uncertainty (IPCC, 2006b). Based on the recommendations of the
IPCC (2006a), uncertainties assigned for IFSM predictions of GHG emissions were \pm 10 and $\pm 20 \%$ for enteric and manure handling $\mathrm{CH}_{4}$, respectively, $\pm 50 \%$ for $\mathrm{N}_{2} \mathrm{O}$, and $\pm 20 \%$ for fuel combustion and upstream emissions. For fossil energy use, $\pm 20 \%$ was used for feed production, animal feeding, animal housing, manure handling, and upstream predictions. For blue water consumption, $\pm 30 \%$ was used for feed production and other purchased feeds and $\pm 20 \%$ was used for other water uses. The uncertainties associated with the prediction of reactive $\mathrm{N}$ components $\left(\mathrm{NH}_{3}\right.$ emissions, leaching and runoff losses,

Table 5. A summary of the farm-gate environmental intensities of representative dairy farms in each region of Pennsylvania

\begin{tabular}{|c|c|c|c|c|}
\hline \multirow{2}{*}{$\begin{array}{l}\text { Region and environmental } \\
\text { intensity }\end{array}$} & \multicolumn{2}{|c|}{ Range $^{1}$} & \multirow[b]{2}{*}{ Mean } & \multirow{2}{*}{$\begin{array}{l}\text { Weighted } \\
\text { mean }^{2}\end{array}$} \\
\hline & Minimum & Maximum & & \\
\hline \multicolumn{5}{|l|}{ Northeast } \\
\hline $\mathrm{GHG}^{3}{ }^{3} \mathrm{~kg}$ of $\mathrm{CO}_{2} \mathrm{e} / \mathrm{kg}$ of $\mathrm{FPCM}^{4}$ & 0.86 & 1.08 & 0.97 & 0.96 \\
\hline Fossil energy, MJ/kg of FPCM & 2.21 & 3.21 & 2.72 & 2.77 \\
\hline Blue water, $\mathrm{L} / \mathrm{kg}$ of $\mathrm{FPCM}$ & 9.07 & 16.48 & 11.97 & 12.03 \\
\hline Reactive $\mathrm{N}, \mathrm{g}$ of $\mathrm{N} / \mathrm{kg}$ of $\mathrm{FPCM}$ & 8.27 & 13.44 & 9.99 & 9.58 \\
\hline \multicolumn{5}{|l|}{ Southeast } \\
\hline $\mathrm{GHG}, \mathrm{kg}$ of $\mathrm{CO}_{2} \mathrm{e} / \mathrm{kg}$ of $\mathrm{FPCM}$ & 0.88 & 1.10 & 0.99 & 1.02 \\
\hline Fossil energy, MJ/kg of FPCM & 2.28 & 3.20 & 2.70 & 2.71 \\
\hline Blue water, L/kg of FPCM & 9.16 & 27.10 & 14.88 & 13.55 \\
\hline Reactive $\mathrm{N}, \mathrm{g}$ of $\mathrm{N} / \mathrm{kg}$ of $\mathrm{FPCM}$ & 8.11 & 12.95 & 10.25 & 10.40 \\
\hline \multicolumn{5}{|l|}{ North central } \\
\hline $\mathrm{GHG}, \mathrm{kg}$ of $\mathrm{CO}_{2} \mathrm{e} / \mathrm{kg}$ of $\mathrm{FPCM}$ & 0.88 & 1.13 & 0.97 & 0.97 \\
\hline Fossil energy, MJ/kg of FPCM & 2.48 & 2.98 & 2.72 & 2.77 \\
\hline Blue water, L/kg of FPCM & 8.83 & 18.03 & 13.08 & 13.14 \\
\hline Reactive $\mathrm{N}, \mathrm{g}$ of $\mathrm{N} / \mathrm{kg}$ of $\mathrm{FPCM}$ & 6.18 & 13.02 & 9.13 & 9.86 \\
\hline \multicolumn{5}{|l|}{ Central } \\
\hline $\mathrm{GHG}, \mathrm{kg}$ of $\mathrm{CO}_{2} \mathrm{e} / \mathrm{kg}$ of $\mathrm{FPCM}$ & 0.91 & 1.11 & 0.99 & 1.00 \\
\hline Fossil energy, MJ/kg of FPCM & 2.29 & 2.97 & 2.57 & 2.46 \\
\hline Blue water, $\mathrm{L} / \mathrm{kg}$ of $\mathrm{FPCM}$ & 8.63 & 18.74 & 12.81 & 12.86 \\
\hline Reactive $\mathrm{N}, \mathrm{g}$ of $\mathrm{N} / \mathrm{kg}$ of $\mathrm{FPCM}$ & 6.62 & 11.69 & 8.69 & 7.82 \\
\hline \multicolumn{5}{|l|}{ South central } \\
\hline $\mathrm{GHG}, \mathrm{kg}$ of $\mathrm{CO}_{2} \mathrm{e} / \mathrm{kg}$ of $\mathrm{FPCM}$ & 0.86 & 1.11 & 0.96 & 0.93 \\
\hline Fossil energy, MJ/kg of FPCM & 2.11 & 3.10 & 2.61 & 2.62 \\
\hline Blue water, $\mathrm{L} / \mathrm{kg}$ of $\mathrm{FPCM}$ & 8.76 & 21.05 & 14.13 & 15.15 \\
\hline Reactive $\mathrm{N}, \mathrm{g}$ of $\mathrm{N} / \mathrm{kg}$ of $\mathrm{FPCM}$ & 7.81 & 15.35 & 9.77 & 9.30 \\
\hline \multicolumn{5}{|l|}{ Northwest } \\
\hline $\mathrm{GHG}, \mathrm{kg}$ of $\mathrm{CO}_{2} \mathrm{e} / \mathrm{kg}$ of $\mathrm{FPCM}$ & 0.90 & 1.13 & 0.98 & 1.02 \\
\hline Fossil energy, MJ/kg of FPCM & 2.54 & 3.17 & 2.82 & 2.79 \\
\hline Blue water, $\mathrm{L} / \mathrm{kg}$ of $\mathrm{FPCM}$ & 8.22 & 16.72 & 12.74 & 13.44 \\
\hline Reactive $\mathrm{N}, \mathrm{g}$ of $\mathrm{N} / \mathrm{kg}$ of $\mathrm{FPCM}$ & 8.87 & 12.93 & 10.15 & 10.54 \\
\hline \multicolumn{5}{|l|}{ Southwest } \\
\hline $\mathrm{GHG}, \mathrm{kg}$ of $\mathrm{CO}_{2} \mathrm{e} / \mathrm{kg}$ of $\mathrm{FPCM}$ & 0.99 & 1.17 & 1.06 & 1.03 \\
\hline Fossil energy, MJ/kg of FPCM & 2.51 & 3.36 & 2.85 & 3.01 \\
\hline Blue water, L/kg of FPCM & 8.29 & 22.75 & 15.40 & 17.59 \\
\hline Reactive $\mathrm{N}, \mathrm{g}$ of $\mathrm{N} / \mathrm{kg}$ of $\mathrm{FPCM}$ & 6.86 & 12.52 & 9.11 & 8.41 \\
\hline \multicolumn{5}{|l|}{ All of Pennsylvania ${ }^{5}$} \\
\hline $\mathrm{GHG}, \mathrm{kg}$ of $\mathrm{CO}_{2} \mathrm{e} / \mathrm{kg}$ of $\mathrm{FPCM}$ & 0.86 & 1.17 & 0.99 & 0.99 \\
\hline Fossil energy, MJ/kg of FPCM & 2.11 & 3.36 & 2.71 & 2.69 \\
\hline Blue water, $\mathrm{L} / \mathrm{kg}$ of $\mathrm{FPCM}$ & 8.23 & 27.10 & 13.57 & 13.98 \\
\hline Reactive $\mathrm{N}, \mathrm{g}$ of $\mathrm{N} / \mathrm{kg}$ of $\mathrm{FPCM}$ & 6.18 & 15.35 & 9.58 & 9.44 \\
\hline
\end{tabular}

${ }^{1}$ Range in values found across 7 to 10 individual farms simulated in each region.

${ }^{2}$ Mean footprints are weighted by the milk produced by each farm type. The Pennsylvania weighted mean is weighted by the amount of milk produced in each region.

${ }^{3} \mathrm{GHG}$ is greenhouse gas emission expressed in $\mathrm{CO}_{2}$ equivalents $\left(\mathrm{CO}_{2} \mathrm{e}\right)$.

${ }^{4} \mathrm{FPCM}$ is milk corrected to $4 \%$ fat and $3.3 \%$ protein.

${ }^{5}$ State means are weighted by the amount of milk produced in each region. 
nitrification and denitrification, fuel combustion, and upstream emissions) were all assigned a value of $\pm 20 \%$. Uncertainties in the prediction of energy use, water use, and $\mathrm{N}$ losses were set based on experience with IFSM predictions and prior comparisons to observed data. A long-term $\mathrm{N}$ balance was also monitored for the simulated farms to help minimize the uncertainty of these predictions.

\section{RESULTS AND DISCUSSION}

\section{Farm and Regional Environmental Footprints}

Intensities of GHG emission, reactive $\mathrm{N}$ emission, fossil energy use, and blue water consumption varied widely across farms (see Supplemental Data; https:/ /doi.org/10.3168/jds.2019-17388) and regions (Table 5). Many factors affected these intensities, including climate, soil characteristics, and farm management. Thus, the data do not show any particular farm type or management strategy as providing the lowest or highest footprint across all of Pennsylvania's farming regions.

Greenhouse gas emission intensity for individual farms varied from 0.86 to $1.17 \mathrm{~kg}$ of $\mathrm{CO}_{2} \mathrm{e} / \mathrm{kg}$ of $\mathrm{FPCM}$ (Table 5). The mean and the mean weighted by the amount of milk produced for farm type and region were equal $\left(0.99 \mathrm{~kg}\right.$ of $\mathrm{CO}_{2} \mathrm{e} / \mathrm{kg}$ of $\left.\mathrm{FPCM}\right)$, indicating that the farms represented the region well as setup in the model. Farms with the lowest intensity in each region were smaller farms, including the 50-cow semiconfinement, intensive grazing, and small Amish farms. These farms used tiestall barns for housing cows where the manure was removed and applied to fields on a daily basis, reducing the amount of methane produced. Farms with the greatest intensity in each region included the 150-cow confinement, 50-cow confinement, and 100-cow organic farms. On these farms, larger manure storages emitted more $\mathrm{CH}_{4}$, and bedded-pack barns emitted $\mathrm{N}_{2} \mathrm{O}$, resulting in increased GHG emissions. Differences in the ranking of farms among the dairy farming regions within Pennsylvania were largely due to the effects of climate and soil type. Therefore, prescriptive mitigation strategies for individual farms are more effective than uniform enforcement of specific strategies across the state.

The range in GHG emission intensities found in these farm simulations (0.86 to $1.17 \mathrm{~kg}$ of $\mathrm{CO}_{2} \mathrm{e} / \mathrm{kg}$ of $\mathrm{FPCM}$ ) were sometimes lower but generally agreed with values found in other studies done under similar climate and production practices. Recent studies using the IFSM gave similar intensities for various dairy production systems throughout the United States (0.74 to 1.13 $\mathrm{kg}$ of $\mathrm{CO}_{2} \mathrm{e} / \mathrm{kg}$ of FPCM; Rotz et al., 2016; Rotz and Thoma, 2017). National assessments for milk produced in 2007 showed somewhat greater intensities of $1.23 \mathrm{~kg}$ of $\mathrm{CO}_{2} \mathrm{e} / \mathrm{kg}$ of FPCM (Thoma et al., 2013) and $1.35 \mathrm{~kg}$ of $\mathrm{CO}_{2} \mathrm{e} / \mathrm{kg}$ of milk (Capper et al., 2009). In a global assessment in the same time period, FAO (2010) reported an intensity for North America of about $1.3 \mathrm{~kg}$ of $\mathrm{CO}_{2} \mathrm{e} / \mathrm{kg}$ of FPCM. These older studies used lower milk productions per cow than is now being obtained, which contributed to a greater intensity. More recent studies conducted in eastern Canada have reported intensities of $1.3 \mathrm{~kg}$ of $\mathrm{CO}_{2} \mathrm{e} / \mathrm{L}\left(1.26 \mathrm{~kg}\right.$ of $\mathrm{CO}_{2} \mathrm{e} / \mathrm{kg}$; Vergé et al., 2013) and $1.12 \mathrm{~kg}$ of $\mathrm{CO}_{2} \mathrm{e} / \mathrm{L}(1.08 \mathrm{~kg}$ of $\mathrm{CO}_{2} \mathrm{e} / \mathrm{kg}$; Jayasundara and Wagner-Riddle, 2014). A study by Herringshaw (2010) compared grazing and confinement based production systems in Iowa and found GHG emissions around $1.04 \mathrm{~kg}$ of $\mathrm{CO}_{2} \mathrm{e} / \mathrm{kg}$ of ECM for all production systems when allocation to beef was not considered for cull animals leaving the farm. With allocation considered, footprints were less (0.68 to $0.96 \mathrm{~kg}$ of $\mathrm{CO}_{2} \mathrm{e} / \mathrm{kg}$ ) and dependent on the allocation method used.

Fossil energy consumption varied from 2.1 to $3.4 \mathrm{MJ} /$ $\mathrm{kg}$ of FPCM across farms and the 7 Pennsylvania farm-

Table 6. Average annual cattle numbers (2018), milk produced, and simulated emissions and resource use for 7 regions and the state of Pennsylvania

Emissions and resource use

\begin{tabular}{|c|c|c|c|c|c|c|}
\hline \multirow[b]{2}{*}{ Region } & \multirow[b]{2}{*}{ Cows, no. } & \multirow[b]{2}{*}{$\begin{array}{c}\text { Milk } \\
\text { production, } \\
\text { Gg }\end{array}$} & \multirow[b]{2}{*}{$\begin{array}{c}\text { Greenhouse gas, } \\
\text { Gg of } \mathrm{CO}_{2} \\
\text { equivalent }\end{array}$} & \multirow[b]{2}{*}{$\begin{array}{c}\text { Fossil } \\
\text { energy, TJ }\end{array}$} & & \\
\hline & & & & & $\begin{array}{c}\text { Blue } \\
\text { water, GL }\end{array}$ & $\begin{array}{c}\text { Reactive N } \\
\text { loss, Gg }\end{array}$ \\
\hline Northeast & 31,167 & 237.7 & 219 & 634 & 2.76 & 2.19 \\
\hline North central & 58,333 & 474.6 & 446 & 1,266 & 6.01 & 4.51 \\
\hline Central & 107,417 & 887.6 & 853 & 2,106 & 11.02 & 6.70 \\
\hline South central & 99.333 & 848.6 & 766 & 2.152 & 12.42 & 7.63 \\
\hline
\end{tabular}


ing regions, with a mean of $2.7 \mathrm{MJ} / \mathrm{kg}$ of FPCM (Table $5)$. In most of these regions, the 100-cow organic farm had the lowest energy consumption, but other farms had similar energy use. Farms with the highest energy consumption per unit of FPCM tended to be smaller farms, including the 50-cow semi-confinement and 50cow confinement farms. Ironically, the small Amish farm was also among the higher energy consumers per unit of FPCM. The greater intensity of energy use on these farms was primarily due to the energy used in the production of feeds purchased and imported to the farm.

Few studies have evaluated life cycle energy consumption on dairy farms for comparison. In previous studies with the IFSM, lower energy footprints (1.5 to $2.2 \mathrm{MJ} /$ $\mathrm{kg}$ of FPCM) were reported for production systems found throughout the United States (Rotz et al., 2016). These farms were mostly larger with greater milk production than those found in Pennsylvania. Thomassen et al. (2008) reported greater values of $5.0 \mathrm{MJ} / \mathrm{kg}$ of FPCM for conventional and $3.5 \mathrm{MJ} / \mathrm{kg}$ of FPCM for organic dairy farms in the Netherlands. Management differences in European systems contribute to this greater energy use.

Across farms and the 7 farming regions, water consumption varied from 8.2 to $27.1 \mathrm{~kg} / \mathrm{kg}$ of FPCM, with a mean of 13.6 and weighted mean of $14.0 \mathrm{~kg} / \mathrm{kg}$ of FPCM (Table 5). The primary source of this variation was the amount of feed purchased. The lowest consumers were the 100-cow organic and intensive grazing operations due primarily to their heavy use of grass and pasture systems with less reliance on grain. In most of the 7 farming regions, the greatest consumers were the larger 1,000-cow and 150-cow confinement operations. Small Amish farms also had greater water use intensities than other farms in some of Pennsylvania's regions due to greater feed purchases.

Water use intensity is low in Pennsylvania, where irrigation is rarely used on dairy farms. The primary source of water use is through purchased feed from other regions where irrigation is sometimes used. In a previous study using IFSM, blue water footprints ranged from 7 to $470 \mathrm{~kg} / \mathrm{kg}$ of FPCM for production systems across the United States, with the lowest values for dairy farms in the humid eastern portion of the country (Rotz et al., 2016). Mekonnen and Hoekstra (2010) estimated an average blue water footprint for milk produced in the United States to be $60 \mathrm{~kg} / \mathrm{kg}$ of milk with a global average of $86 \mathrm{~kg} / \mathrm{kg}$ of milk.

Reactive N losses varied from 6.2 to $15.4 \mathrm{~g}$ of N/kg of FPCM across farm types and regions, with a mean of 9.6 and weighted mean of $9.4 \mathrm{~g}$ of $\mathrm{N} / \mathrm{kg}$ of $\mathrm{FPCM}$ (Table 5). Losses of reactive $\mathrm{N}$ were affected more by differences in climate and soil than by differences in farm management. In some regions, the lowest losses were associated with the small organic and intensive grazing operations, whereas in other regions the large confinement provided the lowest loss per unit of milk. The 100-cow organic farm had the highest loss in many regions, but the 150-cow confinement farm was also high. The high loss from the organic farm was due to a high legume content in the pasture, which led to high protein intake, greater $\mathrm{N}$ excretion, and thus greater $\mathrm{NH}_{3}$ and $\mathrm{N}_{2} \mathrm{O}$ emissions. The reactive $\mathrm{N}$ loss metric is unique to the IFSM model; no other experimental or modeling studies have assessed all forms of $\mathrm{N}$ loss at the whole-farm scale. In a previous IFSM study of dairy production systems across the United States, reactive N footprints ranged from 7.0 to $11.2 \mathrm{~g}$ of $\mathrm{N} / \mathrm{kg}$ of FPCM, with the highest value for a system in Pennsylvania (Rotz et al., 2016).

A major portion of the reactive $\mathrm{N}$ is lost in the form of ammonia, where losses occur from manure on barn floors, during long-term storage, and following field application. Over all farms simulated in Pennsylvania, $49 \%$ of the emitted reactive $\mathrm{N}$ was ammonia. This gave an average annual emission of $66 \mathrm{~kg}$ of $\mathrm{NH}_{3} /$ cow. This value compares well to that found in an extensive comparison of measured and IFSM-predicted ammonia emissions from all farm sources where average annual emissions ranged from $52 \mathrm{~kg}$ of $\mathrm{NH}_{3} / \mathrm{cow}$ on grazing operations with daily manure hauling to $66 \mathrm{~kg}$ of $\mathrm{NH}_{3} /$ cow for operations using freestall housing with longterm storage (Rotz et al., 2014). Through a comprehensive review of reported ammonia emissions from dairy barns, Hristov et al. (2011) found an average emission of $59 \mathrm{~g}$ of $\mathrm{NH}_{3} /$ cow per day. Emissions from barns alone in our study were $15 \%$ less, averaging about $50 \mathrm{~g}$ of $\mathrm{NH}_{3} /$ cow per day (data not shown).

\section{State-Wide Environmental Footprints}

The total GHG emission from dairy farms in Pennsylvania was determined to be 4,555 with an uncertainty of $\pm 415 \mathrm{Gg}$ of $\mathrm{CO}_{2} \mathrm{e}$. Among the 7 farming regions of Pennsylvania, this total was proportional to the number of cows maintained and the resulting milk production (Table 6). A third of the emission was associated with the southeast region, with $69 \%$ from the concentrated dairy regions of the central, south central, and southeast regions. The Pennsylvania Department of Environmental Protection estimated the GHG emissions for the state in 2015 to be $286.8 \mathrm{Tg}$ of $\mathrm{CO}_{2} \mathrm{e}(\mathrm{PA}$ DEP, 2018). This implies that emissions related to milk production on dairy farms are equivalent to $1.6 \%$ of the total state GHG emission. That from agriculture 
was estimated to be $15.4 \mathrm{Tg}$ of $\mathrm{CO}_{2} \mathrm{e}$, so dairy farm emissions are equivalent to about $30 \%$ of this reported source.

Total fossil energy consumption on Pennsylvania dairy farms was determined to be $12,324 \pm 1,946$ TJ (Table 6). The distribution among regions of the state was similar to that of GHG emissions. The US Energy Information Administration (US EIA, 2019) estimated total fossil energy consumption for the state in 2016 to be 3,423 PJ. Thus, that related to milk production on dairy farms compares to $0.4 \%$ of this total consumption.

Blue water consumption related to dairy farms in the state was found to be $64.1 \pm 13.5 \mathrm{Tg}$ (Table 6). Total fresh water use (essentially the same as blue water in our study) in the state was estimated at 22,824 Gg per day (Dieter et al., 2018) for an annual consumption of $8,333 \mathrm{Tg}$. This indicates that water use related to dairy farming is equivalent to $0.8 \%$ of the state consumption of fresh water. That related to livestock production was estimated to be $149.5 \mathrm{Gg}$ per day or $54.6 \mathrm{Tg}$ per year. Thus, our value for dairy alone was greater than their estimate for total livestock. Our life cycle approach includes resource production where a large portion of the water use is from the production of purchased feeds that may come from other states where irrigation is used. This source of water use would not be included in their estimate of livestock consumption.

The total of all forms of reactive $\mathrm{N}$ loss from dairy production in the state was $43.2 \pm 5.0 \mathrm{Gg}$ of $\mathrm{N}$ (Table 6 ). State-level data were not available for comparison to this metric, but the US Environmental Protection Agency (US EPA, 2019) has provided $\mathrm{NH}_{3}$ and $\mathrm{NO}$ emission inventory data. Our prediction of $\mathrm{NH}_{3}$ emission from Pennsylvania dairy farms was $21.7 \mathrm{Gg}$, which is about $50 \%$ of the total state estimate of $44.1 \mathrm{Gg}$. For $\mathrm{NH}_{3}$ and $\mathrm{N}$ oxides together, our value for dairy farms was $23.0 \mathrm{Gg}$ or $4.7 \%$ of the $492 \mathrm{Gg}$ estimate for these emissions statewide.

Mean environmental intensities for dairy farms in the state were determined by dividing the state level values by the total FPCM production for the state. The farmgate GHG emission intensity of the milk produced was $0.99 \pm 0.09 \mathrm{~kg}$ of $\mathrm{CO}_{2} \mathrm{e} / \mathrm{kg}$ of FPCM (Table 5). Fossil energy consumption was $2.69 \pm 0.42 \mathrm{MJ} / \mathrm{kg}$ of FPCM, and blue water consumption was $14.0 \pm 3.0 \mathrm{~kg} / \mathrm{kg}$ of FPCM. Total reactive $\mathrm{N}$ loss related to milk production was $9.4 \pm 1.1 \mathrm{~g} / \mathrm{kg}$ of FPCM. Weighted mean values over all farm types and regions were similar to the unweighted means (Table 5). This supports that environmental intensities were not closely related to farm type and size or region of the state. Many factors contribute to the environmental footprints of a farm, so mitigation practices should be implemented on a specific farm basis.

\section{Sensitivity Analysis}

In this study, GHG emission sources of dairy production include $\mathrm{CH}_{4}$ from enteric fermentation and manure storage; $\mathrm{N}_{2} \mathrm{O}$ from manure, pasture, and cropland; anthropogenic $\mathrm{CO}_{2}$ from liming and fuel combustion; and secondary emissions from the manufacture of resources used on the farm. The GHG emission intensity or carbon footprint was relatively insensitive to combustion sources, slightly sensitive to pasture and cropland $\mathrm{N}_{2} \mathrm{O}$ sources, moderately sensitive to manure and resource production sources, and most sensitive to enteric $\mathrm{CH}_{4}$ (Figure 2). Hence, GHG emission intensity of these dairy production systems was not found to be highly sensitive to any single source. Because the GHG intensity was most sensitive to enteric $\mathrm{CH}_{4}$, reducing emissions from this source has the greatest mitigation potential.

Production of resources used in milk production was the major consumer of fossil energy (see Supplemental Data; https://doi.org/10.3168/jds.2019-17388). Therefore, assumptions related to upstream emissions in resource production had the greatest influence on energy use (Figure 2). Important upstream sources included the production of electricity, fertilizer, and feed. Energy use was found to be slightly sensitive to the electricity used in milking and milk cooling and energy used to produce feed. Total fossil energy use was relatively insensitive to that used in feeding animals and manure handling.

Components of water consumption were purchased feed production, animal drinking and cooling, and parlor cleaning. Irrigation of crops was not used on these dairy farms, so this component had no effect on blue water consumption. Irrigation and water for processing were used to produce purchased feeds. This created high sensitivity to purchased feed water consumption (Figure 2), although the amount of water used was small. The sensitivity of blue water consumption was moderate for drinking and relatively low for cooling and parlor cleaning.

Ammonia emissions from pastures, barns, and manure storages were the main sources of reactive $\mathrm{N}$ loss on all farms. Thus, reactive $\mathrm{N}$ loss was highly sensitive to $\mathrm{NH}_{3}$ emissions, moderately sensitive to $\mathrm{NO}_{3}{ }^{-}$leaching losses, slightly sensitive to $\mathrm{N}_{2} \mathrm{O}$ emissions and $\mathrm{N}$ loss in resource production, and not sensitive to fuel combustion emissions (Figure 2). Efforts to reduce reactive $\mathrm{N}$ losses should focus on reducing or capturing $\mathrm{NH}_{3}$ emissions. Saving this $\mathrm{N}$ for use in feed-crop production 


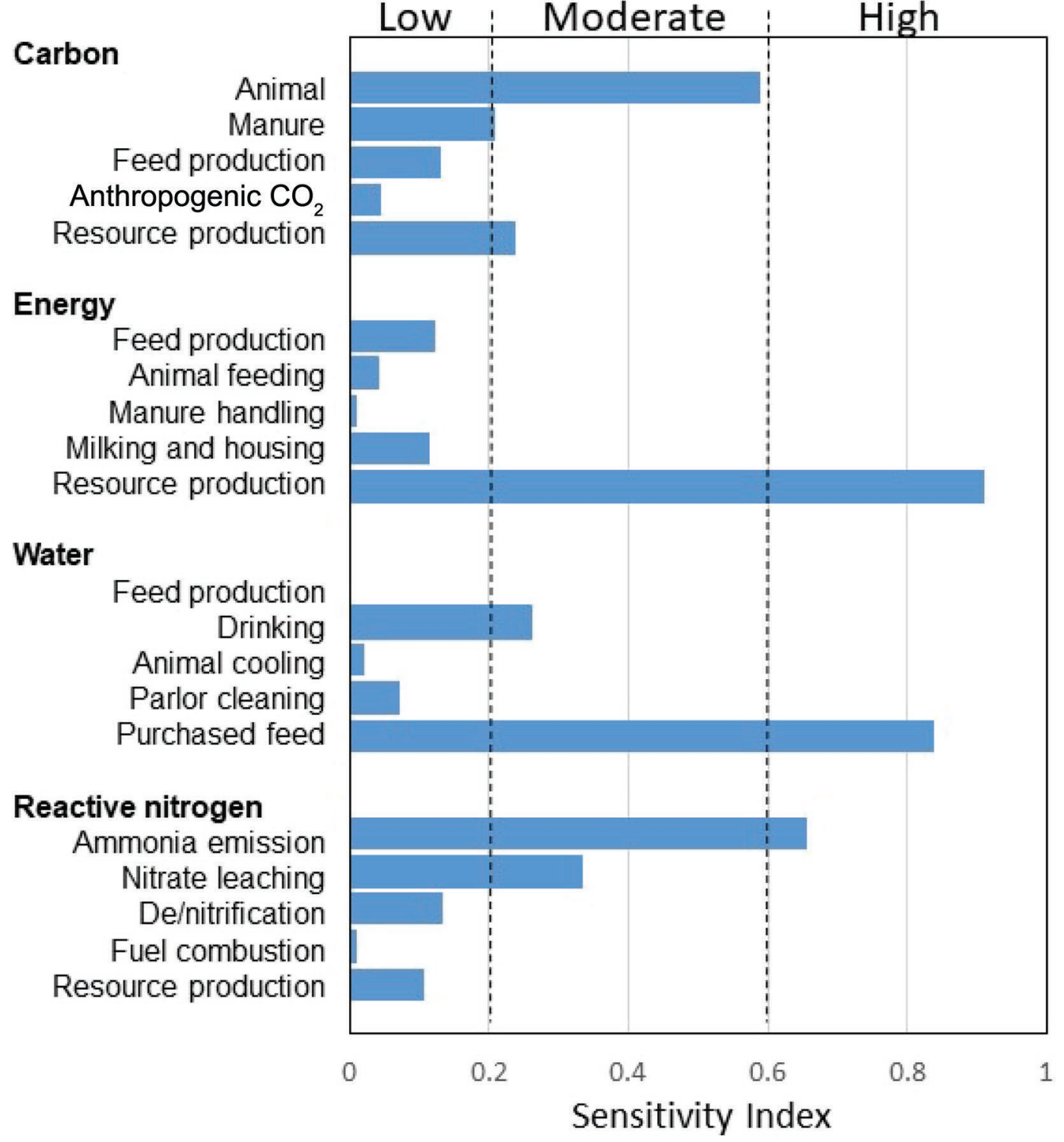

Figure 2. Sensitivity of predicted environmental footprints to changes made in the major sources. The sensitivity index is the ratio of the percent change in output over the percent change in input.

can improve $\mathrm{N}$ use efficiency as well as reduce potential environmental damage. This must be balanced with methods for reducing leaching and denitrification losses to ensure that the saved $\mathrm{N}$ is used in crop uptake and not lost through other pathways.

\section{CONCLUSIONS}

A method was developed that uses process level simulation of dairy farms to quantify important farmgate life cycle emissions and resource consumptions at a regional scale. When applied to the US state of Pennsylvania, as an example of a bounded geographic region in which farm-gate inferences could be compared with impacts from other land uses, the method quantified wide variability in the environmental footprints of dairy farms as affected primarily by soil characteristics and climate and secondarily by farm management. Results indicate that varied mitigation strategies for individual farms are more effective than uniform enforcement of specific strategies across the state. Greenhouse gas emissions, fossil energy use, and blue water use associated with dairy farm production were found to be relatively minor compared with total estimates for the state. Perhaps the greatest of all environmental concerns is that of $\mathrm{NH}_{3}$ emissions, where dairy farms may emit half that estimated for the whole state. This approach provides a method for comprehensive and in- 
depth assessment of environmental footprints of dairy farms that can be applied to other regions and at a national scale.

\section{ACKNOWLEDGMENTS}

USDA is an equal opportunity provider and employer. Funding for this work was provided by the USDA Agricultural Research Service, University Park, Pennsylvania, under project 1902-11130-002, Mitigating emissions and adapting farm systems to climate variability. The authors have not stated any conflicts of interest.

\section{REFERENCES}

Belflower, J. B., J. K. Bernard, D. K. Gattie, D. W. Hancock, L. M. Risse, and C. A. Rotz. 2012. A case study of the potential environmental impacts of different dairy production systems in Georgia. Agric. Syst. 108:84-93. https://doi.org/10.1016/j.agsy .2012.01.005.

Bonifacio, H. F., C. A. Rotz, A. B. Leytem, H. M. Waldrip, and R. W. Todd. 2015. Process-based modeling of ammonia and nitrous oxide emissions from open lot beef and dairy facilities. Trans. ASABE 58:827-846.

Capper, J. L., R. A. Cady, and D. E. Bauman. 2009. The environmental impact of dairy production: 1944 compared with 2007. J. Anim. Sci. 87:2160-2167. https://doi.org/10.2527/jas.2009-1781.

Dieter, C. A., M. A. Maupin, R. R. Caldwell, M. A. Harris, T. I. Ivahnenko, J. K. Lovelace, N. L. Barber, and K. S. Linsey. 2018. Estimated use of water in the United States in 2015: US Geological Survey Circular 1441. Accessed May 10, 2019. https://pubs.er.usgs .gov/publication/cir1441.

FAO. 2010. Greenhouse Gas Emissions from the Dairy Sector: A Life Cycle Assessment. Anim. Prod. Health Div., Food Agric. Org. United Nations, Rome, Italy.

Fox, D. G., L. O. Tedeschi, T. P. Tylutki, J. B. Russell, M. E. Van Amburgh, L. E. Chase, A. N. Pell, and T. R. Overton. 2004. The Cornell net carbohydrate and protein system model for evaluating herd nutrition and nutrient excretion. Anim. Feed Sci. Technol. 112:29-78. https://doi.org/10.1016/j.anifeedsci.2003.10.006.

Herringshaw, A. L. 2010. Evaluation of greenhouse gas emissions from three dairy production systems in Iowa-Conventional, grazing, and combination conventional/grazing. Graduate Theses and Dissertations. 11176. Accessed Jul. 17, 2019. https://lib.dr.iastate .edu/etd/1117.

Hoard's Dairyman. 2019. US dairy 2018 statistics. Hoard's Dairyman Mar. 25 issue: $183-185$.

Holly, M. A., K. M. Gunn, C. A. Rotz, and P. J. A. Kleinman. 2019. Management characteristics of Pennsylvania dairy farms. Appl. Anim. Sci. 35:325-338. https://doi.org/10.15232/aas.2018-01833.

Hristov, A. N., M. Hanigan, A. Cole, R. Todd, T. A. McAllister, P. M. Ndegwa, and A. Rotz. 2011. Review: Ammonia emissions from dairy farms and beef feedlots. Can. J. Anim. Sci. 91:1-35. https:/ /doi.org/10.4141/CJAS10034.

IDF. 2015. A common carbon footprint approach for dairy. Bulletin 479/2015. Int. Dairy Fed., Brussels, Belgium. Accessed Jul. 19, 2019. https://www.fil-idf.org/wp-content/uploads/2016/09/ Bulletin479-2015_A-common-carbon-footprint-approach-for-the -dairy-sector.CAT.pdf.

IPCC (International Panel on Climate Change). 2006a. Guidelines for national greenhouse inventories. Vol. 4: Agriculture, forestry and other land use. Accessed Jul. 19, 2019. http://www.ipcc-nggip.iges .or.jp/public/2006gl/vol4.html.

IPCC (International Panel on Climate Change). 2006b. Guidelines for national greenhouse gas inventories. Vol. 1: General guidance and reporting. Accessed Jul. 19, 2019. http://www.ipcc-nggip.iges.or .jp/public/2006gl/voll.html.

Jayasundara, S., and C. Wagner-Riddle. 2014. Greenhouse gas emissions intensity of Ontario milk production in 2011 compared with 1991. Can. J. Anim. Sci. 94:155-173. https://doi.org/10.4141/ cjas2013-127.

Jego, G., C. A. Rotz, G. Belanger, G. F. Tremblay, E. Charbonneau, and D. Pellerin. 2015. Simulating forage crop production in a northern climate with the Integrated Farm System Model. Can. J. Plant Sci. 95:745-757. https://doi.org/10.4141/cjps-2014-375.

LEAP (Livestock Environmental Assessment and Performance). 2016. Environmental performance of large ruminant supply chains: Guidelines for assessment. Food Agric. Org. Accessed Apr. 23, 2018. http://www.fao.org/3/a-i6494e.pdf.

Leytem, A. B., D. L. Bjorneberg, C. A. Rotz, L. E. Moraes, E. Kebreab, and R. S. Dungan. 2018. Ammonia emissions from dairy lagoons in the western US. Trans. ASABE 61:1001-1015. https:// doi.org/10.13031/trans.12646.

Mekonnen, M. M., and A. Y. Hoekstra. 2010. The green, blue and grey water footprint of farm animals and animal products. Value of Water Research Report Series No. 48. UNESCO-IHE, Delft, the Netherlands.

Myhre, G., D. Shindell, F.-M. Bréon, W. Collins, J. Fuglestvedt, J. Huang, D. Koch, J.-F. Lamarque, D. Lee, B. Mendoza, T. Nakajima, B. Robock, G. Stephens, T. Takemura, and H. Zhang. 2013. Anthropogenic and natural radiative forcing. Page 731 in Climate Change 2013: The Physical Science Basis. Contribution of Working Group I to the Fifth Assessment Report of the Intergovernmental Panel on Climate Change. T. F. Stocker, D. Qin, G.-K. Plattner, M. Tignor, S. K. Allen, J. Boschung, A. Nauels, Y. Xia, V. Bex, and P. M. Midgley, ed. Cambridge Univ. Press, Cambridge, United Kingdom.

NASS. 2019. Quick Stats 2.0. Natl. Agric. Statics Serv., USDA. Accessed Mar. 16, 2018. http://quickstats.nass.usda.gov.

NOAA. 2019. Land-based station data. Natl. Climatic Data Cent., Natl. Ocean. Atmos. Admin. Accessed May 8, 2019. https://www .ncdc.noaa.gov/data-access/land-based-station-data.

NRC. 2001. Nutrient Requirements of Dairy Cattle. 7th rev. ed. NRC, Natl. Acad. Sci., Washington, DC.

NRCS. 2019. Web Soil Survey. Nat. Resour. Conserv. Serv., USDA. Accessed Mar. 16, 2018. http://websoilsurvey.sc.egov.usda.gov/ App/WebSoilSurvey.aspx.

O'Brien, D., J. L. Capper, P. C. Garnsworthy, C. Grainger, and L. Shalloo. 2014. A case study of the carbon footprint of milk from high-performing confinement and grass-based dairy farms. J. Dairy Sci. 97:1835-1851. https://doi.org/10.3168/jds.2013-7174.

PA DEP (Pennsylvania Department of Environmental Protection). 2018. Pennsylvania Greenhouse Gas Inventory. Accessed May 10, 2019. https://www.dep.pa.gov/Business/Energy/ OfficeofPollutionPrevention/climatechange/PublishingImages/ Pages/CCAC/Inventory\%20-\%202018\%20write\%20-up.pdf.

Rotz, C. A., S. Asem-Hiablie, J. Dillon, and H. Bonifacio. 2015. Cradle-to-farm gate environmental footprints of beef cattle production in Kansas, Oklahoma, and Texas. J. Anim. Sci. 93:2509-2519. https://doi.org/10.2527/jas.2014-8809.

Rotz, C. A., S. Asem-Hiablie, S. Place, and G. Thoma. 2019. Environmental footprints of beef cattle production in the United States. Agric. Syst. 169:1-13. https://doi.org/10.1016/j.agsy.2018.11.005.

Rotz, C. A., M. S. Corson, D. S. Chianese, F. Montes, S. D. Hafner, H. F. Bonifacio, and C. U. Coiner. 2018. Integrated Farm System Model: Reference Manual. USDA Agric. Res. Serv., University Park, PA. Accessed Apr. 5, 2019. https://www.ars.usda.gov/ ARSUserFiles/80700500/Reference\%20Manual.pdf.

Rotz, C. A., B. J. Isenberg, K. R. Stackhouse-Lawson, and J. Pollak. 2013. A simulation-based approach for evaluating and comparing the environmental footprints of beef production systems. J. Anim. Sci. 91:5427-5437. https://doi.org/10.2527/jas.2013-6506.

Rotz, C. A., F. Montes, and D. S. Chianese. 2010. The carbon footprint of dairy production systems through partial life cycle assessment. J. Dairy Sci. 93:1266-1282. https://doi.org/10.3168/jds .2009-2162. 
Rotz, C. A., F. Montes, S. D. Hafner, A. J. Heber, and R. H. Grant. 2014. Ammonia emission model for whole farm evaluation of dairy production systems. J. Environ. Qual. 43:1143-1158. https://doi .org/10.2134/jeq2013.04.0121.

Rotz, C. A., R. H. Skinner, A. M. K. Stoner, and K. Hayhoe. 2016. Farm simulation can help dairy production systems adapt to climate change. Pages 91-124 in Advances in Agricultural Modeling. Vol. 7. J. Hatfield and D. Fleisher, ed. Am. Soc. Agron.; Crop Sci. Soc. Am.; Soil Sci. Soc. Am., Madison, WI.

Rotz, C. A., and G. Thoma. 2017. Assessing the carbon footprint of dairy production systems. Pages 19-31 in Large Dairy Herd Management. 3rd ed. D. K. Beede, ed. Am. Dairy Sci. Assoc., Champaign, IL.

Thoma, G., J. Popp, D. Nutter, D. Shonnard, R. Ulrich, M. Matlock, D. Kim, Z. Neiderman, N. Kemper, C. East, and F. Adom. 2013. Greenhouse gas emissions from milk production and consumption in the United States: A cradle-to-grave life cycle assessment circa 2008. Int. Dairy J. 31:S3-S14. https://doi.org/10.1016/j.idairyj 2012.08.013.

Thomassen, M. A., K. J. van Calker, M. C. J. Smits, G. L. Iepema, and I. J. M. de Boer. 2008. Life cycle assessment of conventional and organic milk production in the Netherlands. Agric. Syst. 96:95-107. https://doi.org/10.1016/j.agsy.2007.06.001.

US EIA (Energy Information Administration). 2019. Primary Energy Consumption Estimates, 1960-2016, Pennsylvania. Accessed May 10, 2019.

USDA. 2018. Integrated Farm System Model, version 4.4. Agricultural Research Service, University Park, PA. Accessed Jan. 15, 2019. https://www.ars.usda.gov/northeast-area/up-pa/pswmru/docs/ integrated-farm-system-model/. https://www.eia.gov/state/seds/ data.php?incfile=/state/seds/sep_use/total/use_tot_PAcb.html\& sid $=$ PA.
US EPA (Environmental Protection Agency). 2019. 2014 National Emissions Inventory Report. Accessed May 10, 2019. https:// gispub.epa.gov/neireport/2014/.

Veltman, K., C. A. Rotz, L. Chase, J. Cooper, P. Ingraham, R. C. Izaurralde, C. D. Jones, R. Gaillard, R. A. Larson, M. Ruark, W. Salas, G. Thoma, and O. Jolliet. 2018. A quantitative assessment of beneficial management practices to reduce carbon and reactive nitrogen footprints and phosphorus losses on dairy farms in the US Great Lakes region. Agric. Syst. 166:10-25. https://doi.org/10 .1016/j.agsy.2018.07.005.

Vergé, X. P. C., D. Maxime, J. A. Dyer, R. L. Desjardins, Y. Arcand, and A. Vanderzaag. 2013. Carbon footprint of Canadian dairy products: Calculations and issues. J. Dairy Sci. 96:6091-6104. https://doi.org/10.3168/jds.2013-6563.

von Keyserlingk, M. A. G., N. P. Martin, E. Kebreab, K. F. Knowlton, R. J. Grant, M. Stephenson, C. J. Sniffen, J. P. Harner III, A. D. Wright, and S. I. Smith. 2013. Invited review: Sustainability of the US dairy industry. J. Dairy Sci. 96:5405-5425. https://doi.org/10 $.3168 /$ jds.2012-6354.

Winsten, J., C. Kerchner, A. Richardson, A. Lichau, and J. Hyman. 2010. Trends in the Northeast dairy industry: Large-scale modern confinement feeding and management-intensive grazing. J. Dairy Sci. 93:1759-1769. https://doi.org/10.3168/jds.2008-1831.

\section{ORCIDS}

C. Alan Rotz (1) https://orcid.org/0000-0001-6668-4319

Robert C. Stout (ㄴ) https://orcid.org/0000-0001-5089-3853 